\title{
SUCCESS THROUGH FAILURE
}




\section{OTHER BOOKS BY HENRY PETROSKI}

Pushing the Limits: New Adventures in Engineering Small Things Considered: Why There Is No Perfect Design

Paperboy: Confessions of a Future Engineer The Book on the Bookshelf

Remaking the World: Adventures in Engineering Invention by Design: How Engineers Get from Thought to Thing

Engineers of Dreams: Great Bridge Builders and the Spanning of America

Design Paradigms: Case Histories of Error and Judgment in Engineering

The Evolution of Useful Things

The Pencil: A History of Design and Circumstance

Beyond Engineering: Essays and Other Attempts to Figure without Equations

To Engineer Is Human: The Role of Failure in Successful Design 


\title{
SUCCESS THROUGH FAILURE The Paradox of Design
}

\author{
Henry Petroski
}

PRINCETON University PRESS $\leftrightarrow \quad$ Princeton and Oxford 
Copyright (C) 2006 by Henry Petroski

Requests for permission to reproduce material from this work should be sent to Permissions, Princeton University Press Published by Princeton University Press, 41 William Street, Princeton, New Jersey 08540

In the United Kingdom: Princeton University Press, 3 Market Place, Woodstock, Oxfordshire OX20 1SY

All Rights Reserved

British Library Cataloging-in-Publication Data is available

Library of Congress Cataloging-in-Publication Data

Petroski, Henry.

Success through failure : the paradox of design / Henry Petroski.

p. cm.

Includes bibliographical references and index. ISBN-13: 978-0-691-12225-0 ((hardcover) : alk. paper)

ISBN-10: 0-691-12225-3 ((hardcover) : alk. paper)

1. Engineering design-Case studies. 2. System failures

(Engineering)-Case studies. I. Title.

TA174.P4739 2006

620'.0042-dc22 2005034126

Small portions of this material appeared first in American Scientist,

Harvard Business Review, and the Washington Post Book World

This book has been composed in Adobe Caslon and Helvetica Neue

Printed on acid-free paper. $\infty$

pup.princeton.edu

Printed in the United States of America

135779108642 
